\title{
Extraction and Characterization of The Base Halal Gelatin Based on Bovine Bone
}

\author{
Asrul Bahar \\ Department of Home Economic \\ Department \\ Universitas Negeri Surabaya \\ Surabaya, Indonesia
}

\author{
Rusijono \\ Department education of technology \\ Universitas Negeri Surabaya \\ Surabaya, Indonesia
}

\author{
Nita Kusumawati* \\ Departement of Chemistry \\ Universitas Negeri Surabaya \\ Surabaya, Indonesia \\ nitakusumawati@unesa.ac.id
}

\begin{abstract}
In this study bovine bone material was cured with alkaline solution (calcium oxide) for 10,30 and 50 days and extracted at three temperature levels $\left(60{ }^{\circ} \mathrm{C}\right.$ in extraction I, $70^{\circ} \mathrm{C}$ in extraction II, and $100{ }^{\circ} \mathrm{C}$ in extraction III) each for 4,5 and 6 hours. The results showed an increase in the percentage of yield along with an increase in curing and extraction time, where the preparation with 50 days curing time and 6 hours extraction resulted in the highest gelatin yield percentage, i.e. $23.45 \%$. In addition, the increase in curing and extraction time is also closely related to the increase in proximate levels (water and ash) as well as $\mathrm{pH}$ of bovine bone gelatin. Slightly different, the results of the viscosity and gel strength analysis showed more specific and varied phenomena. Especially for color organoleptic properties, application of various curing and extraction times does not appear to have a significant effect.
\end{abstract}

\section{Keywords-Gelatin, Halal, Base, Bovine, Bone}

\section{INTRODUCTION}

In the production of food, many additives are used to increase food quality, both taste, texture, and color. Monosodium Glutamate (MSG), dyes, gelatin, and so on are the example of additional ingredients. Gelatin is a type of protein that extracted from skin collagen tissue, bones or ligaments (connective tissue) of animals. The production of gelatin by treating animal skin and bone waste. Utilization of gelatin in the food industry is primarily intended to overcome problems that arise especially in the process of product diversification [1].

The necessary of gelatin continuoussly increase from year to year. In 2010, the production of gelatin in world level reach about 326,000 tons/year [2]. Gelatin can be obtained from some of the raw materials, such as pork skin (46\%), bovine skin $(29.4 \%)$, bovine bone $(23.1 \%)$, and other sources $(1.5 \%)$ [3]. To fulfill the domestic demand, Indonesia import 2000-3000 tons of gelatin (2007-2015), with the increasing about 20.26\%/year) from some countries (China, Japan, France, Australia, and New Zealand). The law of Syariat Islam requires their followers have to consume products that are clearly halal. Therefore, as a country with a dominant Muslim population, Indonesia should provide supervision and support for domestic gelatin production, think and remember the abundance of raw material is very large in Indonesia.

The main material in the production of gelatin is collagen, which is a protein that composes the body's tissues of the organism. In general, all parts of the animal's body contain collagen in many variants. The raw materials of bone and skin are the biggest raw material for the gelatin industry because they contain high collagen, available in large quantities and continuous. Basically, the process of producing gelatin from bone and skin tends to be similar, except for raw material preparation, where the raw materials of bone require demineralization before being processed into collagen. According to [4], collagen is spread in several mammalian tissues: $89 \%$ in the skin; $85 \%$ in tendons; $24 \%$ in bone; $23 \%$ in aorta and stomach; $18 \%$ in the colon; $5 \%$ in the kidneys; $2 \%$ in muscles and liver.

Based on the production process, gelatin is divided into 2 types, namely, type A and B gelatin. In type A of gelatin production, raw materials are treated in the form of soaking in an inorganic acids solution, such as hydrochloric acid, sulfuric acid, sulfuric acid or phosphoric acid, so this process known as an acid process, whereas in type B gelatin, the raw material is treated with soaking in alkaline solution (alkaline process) [5] - [6].

Gelatin production is carried out by involving thermal and chemical treatments. The conversion of collagen to gelatin involves the breaking bonds of collagen by strong acids or bases that followed by heating [7]. In general, the production of gelatin is carried out by step by step (multistage extraction) with a relatively low temperature $(50$ $60^{\circ} \mathrm{C}$ ). Purification and drying of gelatin are also carried out by controlled temperatures to reduce the risk of product damage so that it has a wider application.

In general, the main production steps of gelatin are divided into three, namely: (1) preparation of raw materials; (2) conversion of collagen to gelatin; and (3) purification of gelatin by filtration and drying. Raw material preparation includes size reducing, washing, and degreasing. Immersion is carried out by using a strong acid or base solution so that soaking (swelling) make easy the process of extraction. The extraction of gelatin is carried out by step by step to obtain optimal results. At a later stage, gelatin was purified by filtration and drying to obtain $9-16 \%$ moisture content [8] [9].

Research on halal gelatin production is still rare in Indonesia. Some research of gelatin production, including [10] about examining the production of gelatin from bovine bone; [12] - [13] examine the production of gelatin from fish bone; [9], [13] examine gelatin production from chicken claw; and [14] examine gelatin production from fish skin. However, the results of the study have not been able to show the significance of the effectiveness and efficiency of gelatin production from each extraction procedure, both acid and alkaline, especially for raw materials for bovine bone. In 
addition, the lack of information about the effect of operational conditions, such as curing and extraction in quality and quantity of gelatin produced from specific production processes has inhibited the acquisition of gelatin with homogeneous quality.

The size raw material of gelatin becomes an important parameter that also determines the quality of gelatin extraction. Theoretically, the smaller size of the raw material for gelatin, the higher extract obtained, so that it is expected that at the end of the process a larger yield ( $>14-15 \%)$ will be obtained. However, the higher level of difficulty in supplying animal materials with smaller sizes, it is important to know precisely the size of raw material that it is able to produce more extraction results in good quality.

Curing animal materials in alkaline solution really determines the acquisition of collagen that will be converted into gelatin. Therefore, it is important to know precisely by on time that it is able to produce optimum collagen levels. The higher collagen content, the higher content of gelatin produced from the extraction process. The curing time of animal material in an alkaline solution that is too long time has the potential to cause decay in the raw material. While the curing time is too short can cause the optimum collagen acquisition [15].

The extraction time is a parameter that is no less important in the production of gelatin. The right extraction time will provide an opportunity that its needed to break the bond in the animal material matrix can optimal and lead to optimum extraction of the gelatin extracted. While the extraction time which is too long has the potential to cause damage to the source material, not only the gelatin-binding matrix but also damage for the gelatin produced by collagen hydrolysis [15].

\section{MATERIALS AND METHODS}

\section{A. Material of raw}

The raw material of bovine bone that used in this study was obtained from Pegirian-Surabaya Animal Slaughterhouse. In this study, the curing process was carried out using an alkaline solution that made from calcium oxide $(\mathrm{CaO})$ (powder, $\geq 99.99 \%$ ) obtained from Sigma Aldrich (Singapore).

\section{B. Extraction of gelatin from bovine bone}

The process of eextraction was begun by washing the bone until all the dirt is released. The bone material is further reduced the size to $9 \mathrm{~cm}$ and then washed again with pressurized water to clean. The bone material is then heated at $90^{\circ} \mathrm{C}$ temperature for 5 hours, with a comparison a bone: water ratio is 1: $3(\mathrm{~kg} / \mathrm{L})$. Floating debris and appearing foam during heating, are removed. After that, the bone material is drained, and dried under sun exposure. The bone material is roughly ground to the size of $\pm 3 \mathrm{~cm}$. Then the bone material fragments are removed from the mineral content through immersion in $2 \% \mathrm{HCl}$ solution for 24 hours, washed with running water until a neutral $\mathrm{pH}$ is obtained in the rinse water, and then dried. Bone material is then stored in a $10 \% \mathrm{CaO}$ solution (bone / $\mathrm{CaO}(\mathrm{Kg} / \mathrm{L})=1 / 1)$. Curing of bone material is carried out about 10;30; and 50 days. During soaking, then stirring in every two days. This process aims to make ossein in the bones swell. After that, bone material is washed and sprayed with water until the dirt and residual $\mathrm{CaO}$ stick to the bone is eliminated.

Gelatin extraction is carried out using water with a temperature of $600 \mathrm{C}$ (in step 1); $70^{\circ} \mathrm{C}$ (in stage 2); and $100^{\circ} \mathrm{C}$ (in step 3). Gelatin solution extracted from all three steps is collected in a place of evaporation and then heated at a temperature of $50^{\circ} \mathrm{C}$ to thicken and water content below $40 \%$. A thick and still hot gelatin solution is poured into the mold. Then gelatin in silenced until cool and harden. Gelatin which has hardened and removed from the mold, next to be dried using an oven at a temperature of $50^{\circ} \mathrm{C}$ until the water content is below $20 \%$.

\section{Analysis of bovine bone gelatin}

The results of extraction of bovine bone gelatin that was produced in this study were evaluated through the following analysis: (a) proximate (moisture and ash content) respectively referring to the AOAC method no. 927.05 and 942.05 (AOAC, 2000); (b) $\mathrm{pH}$ using a bench meter (ECION51041S; Eutech Instruments, Malaysia); (c) viscosity using viscometer (Minolta CM-3500D; Minolta Co. Ltd., Osaka, Japan); (d) gel strength using a texture analyzer (TX2; Stevens LFRA); and (e) color using a colorimeter (Minolta CM-3500D; Minolta Co. Ltd., Osaka, Japan). Especially for the analysis of $\mathrm{pH}$, viscosity, gel strength and color, it is carried out by referring to standard procedures that were issued by the Institute of America (GMIA) Gelatin Manufacturing.

\section{RESULTS AND DISCUSSION}

\section{A. Extraction of bovine bone gelatin}

The production gelatin of type B bovine bone in this study was carried out by involving a reduction in the size of bovine bone material, which was done to increase bone surface area, so that it was expected to be able to: (1) optimize the dissolution of most mineral salts into $\mathrm{HCl}$ solution; (2) removal of bacteria that was contained in bovine bone material; and (3) facilitate the release of collagen.

In this study, demineralization of bone material in $2 \%$ $\mathrm{HCl}$ for 24 hours that carried out in bone raw materials that have been reduced in size will produce organic materials such as foam that called ossein. To get the GMIA standard gelatin, excess hydrochloric acid after demineralization is removed by washing with running water until obtained a neutral $\mathrm{pH}$ in the wash used water.

After demineralization, gelatin preparation is continued with curing in $\mathrm{CaO}$. Ossein curing process is carried out varies for $10 ; 30$ and 50 days to determine the optimum curing time that needed to induce swelling in ossein so can increase the potential for collagen release when extraction using water solvents. During curing, deamination occurs accompanied by the ammonia revolution. This deamination event has caused damage for intermolecular crosslinks that connect the collagen triple helix polypeptide chain and resulted in a change in the triple helix structure into a double helix.

Before entering the extraction step, bone material is washed thoroughly and is sure to have a neutral $\mathrm{pH}(\mathrm{pH}$ 6-7). This treatment is needed to stop the curing process on ossein. Furthermore, to obtain gelatin extract, extraction was carried out in 3 stages using water solvents. Stage 1 extraction was 
carried out at a temperature of $60{ }^{\circ} \mathrm{C}$, stage 2 at a temperature of $70{ }^{\circ} \mathrm{C}$, and stage 3 at a temperature of $100{ }^{\circ} \mathrm{C}$. The application of a multilevel extraction process at this step is carried out in order to optimize the quality and quantity of gelatin obtained from the extraction step. In addition, to further optimize gelatin recovery, extraction is carried out with varying time, namely 4; 5; and 6 hours.

The extraction process 1 is expected to be able to extract collagen at the lowest depth in ossein material. While extraction 2 and 3 are expected to be able to extract gelatin from ossein material from bovine bones with a higher depth. Extraction results from each stage are left separate, analyzed and can be mixed to obtain gelatin products with the desired specifications. In the extraction process, collagen has been converted into gelatin products through a hydrolysis reaction by following the reaction equation, as shown in Figure 1 .

$$
\begin{aligned}
& \mathrm{C}_{102} \mathrm{H}_{149} \mathrm{~N}_{31} \mathrm{O}_{38}+\mathrm{H}_{2} \mathrm{O} \quad \rightarrow \quad \mathrm{C}_{102} \mathrm{H}_{151} \mathrm{~N}_{31} \mathrm{O}_{39} \\
& \text { Collagen Gelatin }
\end{aligned}
$$

Fig. 1. The equation of collagen hydrolysis reaction to gelatin

In the final step of making type B gelatin, the gelatin extract heated on the stove uses a baking dish at a temperature of $50{ }^{\circ} \mathrm{C}$ for 7 hours. This step is done to optimize evaporation of the water solvent in gelatin. Then the thickened gelatin solution was dried using an oven at 50 ${ }^{\circ} \mathrm{C}$ for 26 hours (moisture content $<16 \%$ ). The drying process is carried out at a relatively low temperature $\left(50^{\circ} \mathrm{C}\right)$ to avoid further breaking of the bond on the gelatin product which will have an impact on the lower viscosity and strength of the gelatin gel produced. In Figure 2 there is a type B dry gelatin product which is produced from bovine bone. While in Figure 3, there is a type $\mathrm{B}$ bovine bone gelatin product which is produced with curing time for 10 days, 30 days and 50 days.

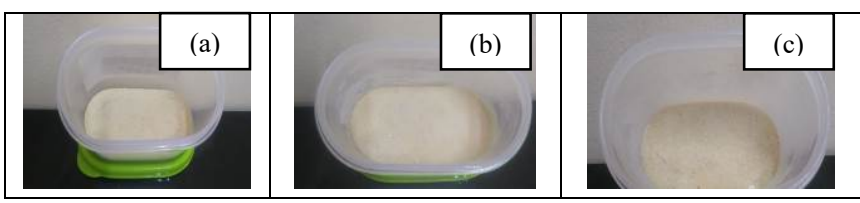

Figure 2. Gelatin base product of bovine bone produced from extraction: (a) 1 ; (b) 2 ; and (c) 3

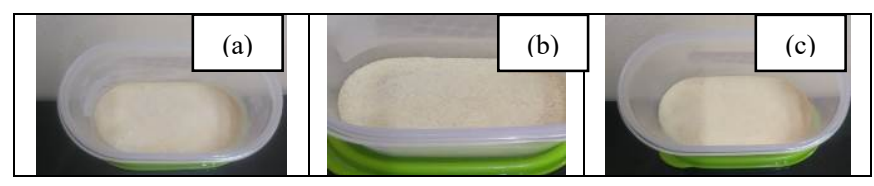

Fig. 3. Gelatin base products of bovine bone base produced from extraction with curing time: (a) 10 days; (b) 30 days; and (c) 50 days

In line with this, to determine the extraction time that is able to produce bovine bone gelatin products with optimum quality and quantity, the production of type B bovine bone gelatin with extraction time for 4 hours, 5 hours, and 6 hours is carried out. In Figure 4, we can see type B bovine bone gelatin products, each produced with extraction time for 4 hours, 5 hours, and 6 hours.

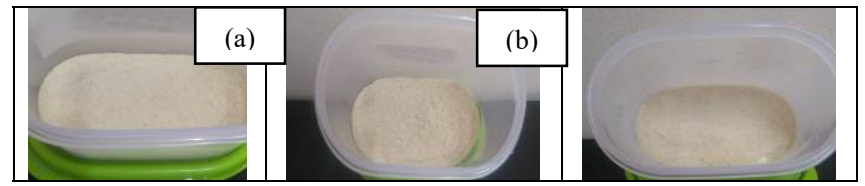

Fig. 4. Gelatin base product of bovine bone produced from extraction time: (a) 4 hours; (b) 5 hours; and (c) 6 hours

\section{B. Analysis of halal type B halal gelatin}

Table 1 shows the results of analysis of type B bovine bone gelatin produced at each curing time. These results indicate that 60 days curing time has produced in higher percentage of yield that compared to 10 days and 20 days. The higher percentage of yield produced from 60 days curing time is due to the longer time that available for the base curing solution to decompose the collagen triple helix structure. The more collagen triple helix structures are decomposed, the more quantity of collagen extracted and then converted to gelatin.

In general, type B bovine gelatin products produced by curing take a long time will have: (1) higher moisture content. The application of curing in a long time has caused more water molecules to be absorbed into the bone material with a certain depth. This condition has a direct impact on the increased moisture content of gelatin products, (2) higher ash content. This condition can occur because the application of increasing curing time has the potential mostly good to dissolve various kinds of minerals so that the resulting gelatin ash content should be lower. Adsorption up to a high depth level on ossein material has made it difficult to process the $\mathrm{pH}$ neutralization by washing method, resulting in a fairly high curing compound deposition in the raw material. With the helping of heat energy available at the time of extraction, the curing compound is also extracted with collagen in the water solvent. Thus, the presence of curing compounds that are mostly high actually results in an increased in the ash content of the gelatin products produced, (3) a higher $\mathrm{pH}$. Deposition of curing compounds with increasing curing time causes base compound deposition in raw material which is then extracted with collagen in water solvent, (4) higher viscosity. Increased curing time has provided a longer chance for curing compounds to describe the triple helix structure of collagen proteins so as to facilitate the extraction of collagen into water solvents. The more collagen particles extracted in water, the higher the density of the particles in the gelatin solution obtained, thus increasing the viscosity of the gelatin product concerned, (5) the gel strength is higher. The increasing curing time has caused the optimum decomposition process of the triple helix structure of collagen protein. The simpler the structure of the collagen protein molecule the higher the potential to be extracted and then converted to gelatin in water solvents, and (6) the product color that does not show any real differences as a result of increased curing time applied to the preparation process.

TABLE I. DATA ON THE QUALITY OF TYPE B BOVINE BONE GELATIN PRODUCTS WITH VARYING CURING TIMES

\begin{tabular}{|l|l|c|c|c|}
\hline \multirow{2}{*}{ No } & \multirow{2}{*}{ Quality Parameter } & \multicolumn{3}{|c|}{$\begin{array}{c}\text { Curing Time (days) (We are } 4 \\
\text { hours) }\end{array}$} \\
\cline { 3 - 5 } & & $\mathbf{1 0}$ & $\mathbf{3 0}$ & $\mathbf{5 0}$ \\
\hline 1 & Rendemen (\%) & 18,15 & 20,54 & 23,07 \\
\hline 2 & Water Content (\%) & 3,5 & 4,3 & 7,2 \\
\hline 3 & Ash Content (\%) & 11,57 & 11,75 & 11,91 \\
\hline
\end{tabular}




\begin{tabular}{|l|l|c|c|c|}
\hline \multirow{2}{*}{ No } & \multirow{2}{*}{ Quality Parameter } & \multicolumn{3}{|c|}{$\begin{array}{c}\text { Curing Time (days) (We are 4 } \\
\text { hours) }\end{array}$} \\
\cline { 3 - 5 } & & $\mathbf{1 0}$ & $\mathbf{3 0}$ & $\mathbf{5 0}$ \\
\hline 4 & $\mathrm{pH}$ & 6,43 & 7,13 & 8,65 \\
\hline 5 & Viscosity (mps) & 19,60 & 20,80 & 21,20 \\
\hline 6 & Strength Gel (bloom) & 43,39 & 45,28 & 49,75 \\
\hline 7 & Colors & white & white & White \\
\hline
\end{tabular}

Table II shows the results of the analysis of the quality of type B bovine bone gelatin products produced at each extraction time. The data shows that the longer extraction time at each stage (6 hours) will produce: (1) the percentage of yield is higher than the shorter extraction time (4 hours and 5 hours). In line with this, type B bovine gelatin products produced from longer extraction times will have: (1) higher moisture content, (2) higher ash content, (3) higher $\mathrm{pH}$, (4) higher viscosity, (5) gel strength is higher, and (6) product color is darker compared to type B beef bone gelatin products produced from the production process with shorter extraction time.

TABLE II. RESULTS OF ANALYSIS OF TYPE B BOVINE BONE GELATIN PRODUCTS PRODUCED FROM 30 DAYS CURING TIME AND EXTRACTION TIME VARIED

\begin{tabular}{|l|l|c|c|c|}
\hline \multirow{2}{*}{ No } & \multirow{2}{*}{ Quality Parameter } & \multicolumn{3}{|c|}{ Extraction Time (hours) } \\
\cline { 3 - 5 } & & $\mathbf{4}$ & $\mathbf{5}$ & $\mathbf{6}$ \\
\hline 1 & Rendemen (\%) & 20,54 & 21,69 & 23,45 \\
\hline 2 & Water Content (\%) & 4,3 & 8,5 & 10 \\
\hline 3 & Ash Content (\%) & 11,39 & 11,50 & 11,75 \\
\hline 4 & pH & 7,13 & 7,29 & 7,45 \\
\hline 5 & Viscosity (mps) & 10,10 & 20,80 & 26,00 \\
\hline 6 & Strength Gel (bloom) & 45,28 & 46,52 & 47,82 \\
\hline 7 & Color & white & $\begin{array}{c}\text { Yellowish } \\
\text { white }\end{array}$ & $\begin{array}{c}\text { Brownish } \\
\text { yellow }\end{array}$ \\
\hline
\end{tabular}

Increasing extraction time, in general, will increase the opportunity for extraction of gelatin protein, both with simple and more complex molecular structures. This is what causes a higher percentage of yield, viscosity value and gel strength resulting from the production process of type B beef bone gelatin with longer extraction time. In line with this, increasing extraction time will cause a certain amount of water solvent volume to evaporate, leaving a solution of thick gelatin containing less water. However, along with these conditions several weaknesses arise in the specific gelatin products obtained, where the increase in extraction time has provided a longer chance for the extraction of curing solution which is deposited in bone raw material and not washed out when the neutralization process is carried out using the washing method. These conditions have subsequently caused the specific gelatin products obtained to have higher ash content and $\mathrm{pH}$. In addition, an increase in extraction time that is longer will also increase the potential for breaking several bonds to the gelatin compounds obtained. The occurrence of molecular structural changes that occur in gelatin, especially if later accompanied by the presence of unpaired electrons in gelatin compounds, will increase the excitation potential of electrons from nonbonding orbitals (n) to the $\delta$ orbitals and $\pi$ orbitals when adsorbing photons. This condition will automatically cause a shift in the wavelength of the gelatin product uptake from the ultraviolet (UV) spectrum to the visible UV spectrum (UV Vis) and induce the appearance of increasingly dark colors on the gelatin product obtained along with the increase in extraction time.

\section{CONCLUSION}

In this study, an evaluation of the effect of the application of curing and extraction time on the quality and quantity of beef bone gelatin products has been carried out. In general, the results of the analysis showed a specific pattern of influence on the percentage of gelatin recovery as well as a number of quality parameters such as proximate levels (water and ash), $\mathrm{pH}$, viscosity, gel strength, and color. The percentage of acquisition of beef bone gelatin in this study varied in the range of $18.15 \%-23.45 \%$. In addition, halal type B gelatin products from raw materials of beef bones produced in this study have: (a) water content of $3.5 \%$ $-10 \%$; (b) ash content of 11.39\% -11.91\%; (c) pH 6.43-8.65; (d) viscosity $10.10 \mathrm{cP}-26.00 \mathrm{cP}$; (e) strength of gel 43.49 bloom - 49.75 bloom; and (f) white - brownish yellow.

\section{ACKNOWLEDGMENT}

Thank you to the Ministry of Research and Technology of the Republic of Indonesia Higher Education for providing financial support through the Higher Education Superior Research Program for 2018 Fiscal Year.

\section{REFERENCES}

[1] http://kesmevet.ditjennak.pertanian.go.id (accessed on August 30 2018)

[2] S.F. See, P.K. Hong, K. L. Ng, W.M. Wan Aida, A.S. Babji, "Physicochemical properties of gelatins extracted from skins of different freshwater fish species," International Food Research Journal, 17, pp. 809-816, 2010.

[3] Harianto, Tazwir, R. Peranginan, "Study of Fish Gelatin Drying Technique with Cabinet Dryer Tool (Studi Teknik Pengeringan Gelatin Ikan dengan Alat Pengering Kabinet)", Laporan Teknis. Jakarta, Balai Besar Penelitian Pengolahan Produk dan Bioteknologi Kelautan dan Perikanan, 2008.

[4] G. Ward, A. Courts, Molecular Nutrition and Food Research, 22 (4), pp. 444-454, 1977.

[5] A. H. Grobben, P.J. Steele, R.A. Somerville, D.M. Taylor, Biotechnology and Applied Biochemistry, 39, pp. 329-338, 2004.

[6] W. Trilaksani, M. Nurilmala, I. H. Setiawati, 2012, JPHPI. 15(3) pp. 240-251.

[7] Heynke dan Roland. 2006. Gelatin Production and Prion Theory. General Information about Gelatin and MadCow Disease including references to various studies. [21 April 2007].

[8] Nhari, R. M. H. R., Ismail, A., Che Men, T. B, 2012. Journal of Food Science. 77 (1) : 42.

[9] Sompie, M., Mirah, A.D., C.H. Linda, Karisoh, M. Prosiding Seminar Nasional Masyarakat Biodiversitas Indonesia. 1(4) : 792-795, 2015.

[10] Atmoko, I.D., Pangestuti, R. D. Laporan Penelitian. Semarang : Universitas Diponegoro, 2011.

[11] Nurilmala M, Tesis. Bogor : Sekolah Pasca sarjana IPB, 2004.

[12] Hariyanto, Sambudi, Y. J. Tugas Akhir. Surakarta : Universitas Sebelas Maret, 2010.

[13] Hidayati, Kuni. Skripsi. Tidak dipublikasikan. Yogyakarta Universitas Islam Negeri Sunan Kalijaga, 2014.

[14] Trilaksani, W., Nurilmala, M., Setiawati, I. H.. JPHPI, 2012, 15(3) : 240-251.

[15] Bahar, A., Kusumawati, N., Anggarani, M.A., Muslim, S. Advances in Social Science, Education and Humanities Research, 2018, 112 : 58-62. 